\title{
Volatilome Analyses and In Vitro Antimicrobial Activity of the Essential Oils from Five South African Helichrysum Species
}

\author{
Basma Najar ${ }^{1, *(\mathbb{D}}$, Valeria Nardi ${ }^{1}$, Claudio Cervelli ${ }^{2}$, Giulia Mecacci ${ }^{1}$, Francesca Mancianti ${ }^{3,4}{ }^{\circ}$, \\ Valentina Virginia Ebani ${ }^{3,4}$, Simona Nardoni ${ }^{3}$ (ID) and Luisa Pistelli ${ }^{1,4}$ \\ 1 Dipartimento di Farmacia, Università di Pisa, Via Bonanno 6, 56126 Pisa, Italy; \\ nardivaleria12@gmail.com (V.N.); g.mecacci@studenti.unipi.it (G.M.); luisa.pistelli@unipi.it (L.P.) \\ 2 CREA-Centro di Ricerca Orticoltura e Florovivaismo, Corso Inglesi 508, 18038 Sanremo, Italy; \\ claudio.cervelli@crea.gov.it \\ 3 Dipartimento di Scienze Veterinarie, Università di Pisa, Viale delle Piagge 2, 56124 Pisa, Italy; \\ francesca.mancianti@unipi.it (F.M.); valentina.virginia.ebani@unipi.it (V.V.E.); \\ simona.nardoni@unipi.it (S.N.) \\ 4 Centro Interdipartimentale di Ricerca Nutraceutica e Alimentazione per la Salute "Nutrafood", \\ Università di Pisa, Via del Borgetto 80, 56124 Pisa, Italy \\ * Correspondence: basmanajar@hotmail.fr
}

Academic Editors: Francesca Mancianti and Valentina Virginia Ebani Received: 22 June 2020; Accepted: 10 July 2020; Published: 13 July 2020

Abstract: Helichrysum genus was used in folk South African medicine to treat various human disorders. As a part of our on-going research addressing the exploitation of South African plants belonging to this genus, five species were investigated for their volatile and antimicrobial activities. The volatile organic compounds (VOCs) and the essential oils (EOs) were analysed by gas chromatography mass spectrometry (GC-MS). Microdilution was the method used for assessing both antimycotic and antibacterial activities, which was also tested by Kirby-Bauer agar disc diffusion. Total monoterpenes (TMs) dominated the VOCs of four species (H. trilineatum $(70.6 \%)$, H. edwardsii $(79.3 \%)$, H. cooperi $(84.5 \%)$, and H. pandurifolium (57.0\%)). H. cooperi and H. edwardsii EOs showed the predominance of TMs (68.2\% and $84.5 \%$, respectively), while H. pandurifolium and H. trilineatum EOs were characterized by the prevalence of TSs ( $86.5 \%$ and $43.6 \%$, respectively). H. odoratissimum EO evidenced a similar amount of both TMs (49.5\%) and TSs (46.4\%). Microsporum canis was more sensitive to these EOs. The lowest minimum inhibitory concentration (MIC) was observed with H. pandurifolium and H. edwardsii EOs $(0.25 \%)$. H. pandurifolium and H. trilineatum had a good effect on Staphylococcus aureus (MIC 5\%). These findings open new perspectives for the exploitation of these natural compounds for application in cosmetics and pharmaceutics.

Keywords: H. cooperi; H. edwardsii; H. pandurifolium; H. odoratissimum; H. trilineatum; HS-SPME; GC-MS; Kirby-Bauer agar disc diffusion; microdilution test

\section{Introduction}

Among the 600 species listed in the Helichrysum genus (Asteraceae family), almost forty percent occur in South Africa. They are subdivided into 30 morphological groups where the only characters that differ are the shape and size of the flower heads [1]. Local indigenous people widely used these plants since antiquity and then enticed the interest of scientists by their richness in unusual secondary metabolites. Numerous organic solvents were used to extract these metabolites and to benefit from their biological activity. 
In 2008, Lourens [2] with colleagues published a review about the traditional uses, biological activity, and phytochemistry of South African Helichrysum species and enumerated seventy species. Three years later, the same team investigated the antimicrobial effects and in vitro cytotoxicity of these same species together with six new ones [3]. Since then, few new species were investigated even though new reports were present in the literature to consolidate and confirm what was previously found in the species and already cited; Lourens et al. Mamabolo [4], for example, have evaluated the antigonorrhea and cytotoxicity of H. caespititium (DC.) Harv. This species together with H. odoratissumum L. Sweet and H. petiolare Hilliard and B.L. Burtt were the subject of three reviews published recently by Maroyi [5-7], who brought to days the traditional medicinal uses, phytochemistry, and biological activities of the cited species.

Besides the species already mentioned by Lourens, new taxa were studied such as $H$. niveum Graham reported by Popoola [8]. Yadizi, in his turn, studied the anti-HIV screening of extracts from thirty-two South African Helichrysum spp., some of them (nineteen) never reported before [9]. However, the authors cited hitherto focused on extracts with organic solvents of the South African Helichrysum species rather than on the essential oils, obtained by hydrodistillation or steam distillation. Turning back to the Lourens reports, before his first review, in 2004, he published an article on the biological activity of the essential oils of four indigenous species [10]. It did not prevent other researchers, fascinated by the biological activities of Helichrysum essential oils, from also investing in several species such as H. kraussii Sch. Bip together with H. rugulosum Less [11], H. aureonitens Sch. Bip. essential oil (EO) [12], and H. cymosum (L.) D. Don [13]. H. odoratissimum was analysed by Asekun, who investigated the effect of drying methods on the essential oil compositions dete [14]. In the last decade, essential oils of other species were also considered such as H. foetidum, investigated by Samie and co-workers [15], who focused on the antimicrobial activity of the $\mathrm{EO}$ of this species without revealing its chemical composition. Moreover, the EOs of the species H. cymosum, H. petiolare [16], H. odoratissimum [16,17], and H. splendidum $[18,19]$ were also investigated. All these authors used plant material collected directly from South Africa; others, on the contrary, decided to cultivate seeds imported from this region in different environments. As a part of our on-going collaboration with CREA (Centro di Ricerca Orticoltura e Florovivaismo) in Sanremo (Italy), we focused on the exploitation of South African Helichrysum species for ornamental and industrial application, and H. nudifolim [20], H. cymosum L., and H. tenax M.D. Hend [21], as well as other eight species [22], were studied for their volatilome.

Continuing in this project, five new South African species of Helichrysum, grown in Italy, were the subject of this work where, after the first step on the chemical composition of both spontaneous emissions and essential oils, the antimycotic and antibacterial activities of the essential oils were assessed.

\section{Results and Discussion}

\subsection{Aroma Profile}

The aromatic profile of the studied species of Helichrysum reveals the presence of 32 different compounds with a percentage of identification ranging from $99.8 \%$ to $100 \%$ (Table 1). Only four compounds are common in all the species, even though with different percentages. These constituents were sabinene ( $0.1 \%$ in $H$. pandurifolium to $34.4 \%$ in $H$. cooperi), $\beta$-pinene (from $2.5 \%$ in $H$. cooperi to $17.5 \%$ in $H$. pandurifolium), $\alpha$-copaene (from $0.2 \%$ in $H$. trilineatum to $2.5 \%$ of $H$. cooperi), and $\beta$-caryophyllene ( $0.7 \%$ in H. cooperi and $6.9 \%$ in H. edwardsii).

All the spontaneous emissions of the studied species were characterized by a high percentage of monoterpene hydrocarbons (Figure 1, Table 2). The amount ranged from $54.7 \%$ in H. pandurifolium to more than $69 \%$ of the total identified fraction in $H$. trilineatum. Sabinene $(34.4 \%)$ and 1,8 -cineole $(20.5 \%)$ were the predominant constituents in $H$. cooperi, while $\alpha$-pinene was the major one in $H$. pandurifolium and $H$. trilineatum ( $25.7 \%$ and $64.8 \%$, respectively) followed by a good percentage of $\beta$-pinene $(17.5 \%)$ in the case of H. pandurifolium. However, more than the $80 \%$ of monoterpene compounds in H. edwardsii were represented by sabinene $(29.2 \%), \beta$-pinene $(16.4 \%)$, and $\beta$-thujone $(18.0 \%)$. Sesquiterpene 
hydrocarbons was the second main class of compounds and the highest amount was evidenced in $H$. pandurifolium $(35.2 \%)$. $\delta$-cadinene was of the main component, which represented more than $52 \%$ of the total sesquiterpenes.

Table 1. Identified compounds in spontaneous emissions of the studied Helichysum spp. (for chromatograms, see Table S1 in Supplementary Materials).

\begin{tabular}{|c|c|c|c|c|c|c|c|c|}
\hline & Compounds* & Class & RIexp & R Lit & H. cooperi & H.edwardsii & H.pandurifolium & H. trilineatum \\
\hline & & & & & \multicolumn{4}{|c|}{ Relative Abundance (\%) } \\
\hline 1 & $\alpha$-thujene & $\mathrm{mh}$ & 930 & 924 & $2.4 \pm 0.4$ & $2.9 \pm 0.1$ & - & $0.4 \pm 0.1$ \\
\hline 2 & $\alpha$-pinene ${ }^{<}$ & $\mathrm{mh}$ & 939 & 932 & $9.2 \pm 1.0$ & - & $25.7 \pm 4.8$ & $64.8 \pm 2.9$ \\
\hline 3 & sabinene $\angle$ & $\mathrm{mh}$ & 974 & 969 & $34.4 \pm 4.3$ & $29.2 \pm 1.4$ & $0.1 \pm 0.0$ & $0.2 \pm 0.0$ \\
\hline 4 & $\beta$-pinene ${ }^{L}$ & $\mathrm{mh}$ & 979 & 974 & $2.5 \pm 0.2$ & $16.4 \pm 1.7$ & $17.5 \pm 4.8$ & $2.8 \pm 1.1$ \\
\hline 5 & myrcene $\angle$ & $\mathrm{mh}$ & 991 & 988 & - & $1.1 \pm 0.0$ & $2.3 \pm 1.1$ & $0.2 \pm 0.1$ \\
\hline 6 & $\alpha$-phellandrene ${ }^{<}$ & $\mathrm{mh}$ & 1003 & 1002 & $2.3 \pm 0.5$ & $0.5 \pm 0.0$ & - & - \\
\hline 7 & $\alpha$-terpinene $\angle$ & $\mathrm{mh}$ & 1017 & 1014 & $6.1 \pm 1.1$ & $2.1 \pm 0.2$ & $0.1 \pm 0.1$ & $0.1 \pm 0.1$ \\
\hline 8 & p-cymene $<$ & $\mathrm{mh}$ & 1025 & 1020 & $1.5 \pm 0.0$ & - & - & - \\
\hline 9 & sylvestrene & $\mathrm{mh}$ & 1027 & 1025 & - & $3.8 \pm 0.2$ & - & - \\
\hline 10 & limonene $\angle$ & $\mathrm{mh}$ & 1029 & 1024 & - & - & $2.0 \pm 0.92$ & $0.5 \pm 0.3$ \\
\hline 11 & 1,8-cineole ${ }^{<}$ & om & 1031 & 1026 & $20.5 \pm 0.7$ & - & $1.0 \pm 0.16$ & $0.2 \pm 0.1$ \\
\hline 12 & (Z)- $\beta$-ocimene & $\mathrm{mh}$ & 1037 & 1032 & - & - & $6.2 \pm 2.84$ & $0.1 \pm 0.1$ \\
\hline 13 & $\gamma$-terpinene $<$ & $\mathrm{mh}$ & 1060 & 1054 & $1.5 \pm 0.0$ & $3.1 \pm 0.3$ & $0.1 \pm 0.06$ & $0.4 \pm 0.2$ \\
\hline 14 & terpinolene $\angle$ & $\mathrm{mh}$ & 1088 & 1086 & - & $1.1 \pm 0.1$ & - & - \\
\hline 15 & cis-thujone $^{L}$ & om & 1103 & 1101 & - & $1.3 \pm 0.2$ & - & - \\
\hline 16 & trans-thujone $<$ & om & 1114 & 1112 & - & $18.0 \pm 1.4$ & - & - \\
\hline 17 & allo-ocimene & om & 1132 & 1128 & - & - & $1.1 \pm 0.6$ & - \\
\hline 18 & $\delta$-elemene & sh & 1338 & 1335 & $0.3 \pm 0.1$ & - & - & $2.4 \pm 0.5$ \\
\hline 19 & $\alpha$-copaene ${ }^{L}$ & sh & 1377 & 1374 & $2.5 \pm 0.3$ & $2.1 \pm 0.1$ & $0.9 \pm 0.3$ & $0.2 \pm 0.0$ \\
\hline 20 & italicene & sh & 1403 & 1405 & $1.0 \pm 0.3$ & $\begin{array}{c}2.1+0.1 \\
-\end{array}$ & - & $\begin{array}{l}-2-0.0 \\
-\end{array}$ \\
\hline 21 & $\beta$-caryophyllene ${ }^{L}$ & sh & 1419 & 1417 & $0.7 \pm 0.0$ & $6.9 \pm 0.8$ & $6.8 \pm 1.9$ & $4.0 \pm 0.1$ \\
\hline 22 & cis-thujopsene & sh & 1431 & 1429 & - & - & $\begin{array}{c}0.01 \\
-\end{array}$ & $\begin{array}{l}-1.1 \\
-\end{array}$ \\
\hline 23 & $\beta$-copaene & sh & 1432 & 1430 & $0.3 \pm 0.0$ & - & - & $1.0 \pm 0.1$ \\
\hline 24 & $\alpha$-humulene $\angle$ & $\mathrm{sh}$ & 1455 & 1452 & $0.3 \pm 0.0$ & & $0.3 \pm 0.2$ & $1.9 \pm 0.2$ \\
\hline 25 & allo-aromadendrene & sh & 1460 & 1458 & - & $0.4 \pm 0.0$ & $0.9 \pm 0.3$ & $0.3 \pm 0.0$ \\
\hline 26 & $\gamma$-muurolene & sh & 1480 & 1478 & $4.1 \pm 0.5$ & - & $0.2 \pm 0.1$ & $0.2 \pm 0.0$ \\
\hline 27 & germacrene D & sh & 1485 & 1484 & $1.4 \pm 0.1$ & - & $0.1 \pm 0.1$ & $9.7 \pm 3.6$ \\
\hline 28 & $\alpha$-muurolene & sh & 1499 & 1500 & - & $4.4 \pm 0.2$ & - & - \\
\hline 29 & bicyclogermacrene & $\mathrm{sh}$ & 1500 & 1500 & $0.8 \pm 0.2$ & - & - & $4.5 \pm 1.5$ \\
\hline 30 & $\delta$-cadinene & sh & 1524 & 1522 & - & $0.4 \pm 0.0$ & $22.0 \pm 4.5$ & $0.2 \pm 0.0$ \\
\hline 31 & viridiflorol & os & 1591 & 1592 & - & - & $6.9 \pm 1.6$ & - \\
\hline 32 & octyl ether & nt & 1659 & $1657 \S$ & - & $3.7 \pm 0.0$ & - & - \\
\hline
\end{tabular}

* Compounds present with percentage $\geq 1 \%$ in at least one of the Helichrysum spp. Data are reported as mean values $(n=3 \pm \mathrm{SD})$; L.R.I ${ }^{\mathrm{exp}}$, linear retention time experimentally determined; L.R.I ${ }^{\text {lit }}$, linear retention time reported by Adams 2007 (26); § linear retention time in pubchem (www.pubchem.ncbi.nlm.nih.gov). ${ }^{\circ}$ compounds identified by comparison to injected authentic reference samples purchased from Sigma-Aldrich, Inc. Bold format: Main constituents.

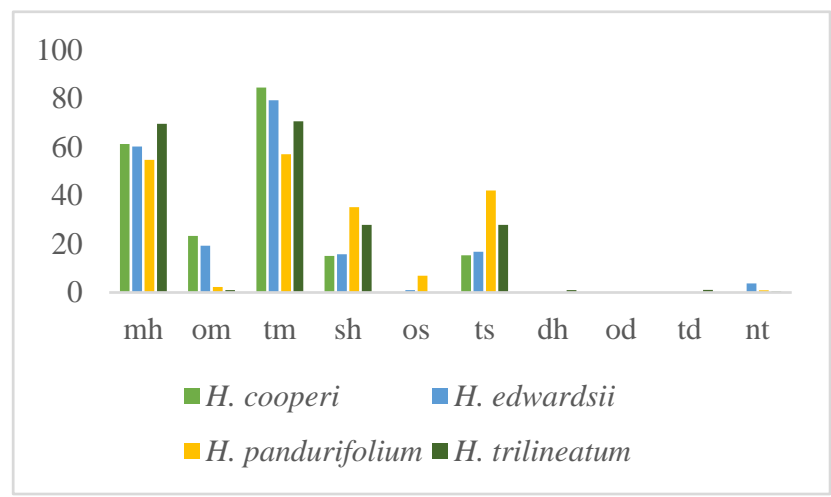

Figure 1. Variation of the class of compounds in the volatile organic compounds (VOCs) of the studied Helichrysum spp. mh: monoterpenes hydrocarbons; om: oxygenated monoterpenes; tm: total monoterpenes; sh: sesquiterpene hydrocarbons; os: oxygenated sesquiterpenes; ts: total sesquiterpenes; dh: diterpene hydrocarbons; od: oxygenated diterpenes; td: total diterpenes; nt: non-terpene derivatives. 
Table 2. Class of compounds in spontaneous emissions of the studied Helichysum spp.

\begin{tabular}{ccccc}
\hline Chemical Classes & H. cooperi & H. edwardsii & H. pandurifolium & H. trilineatum \\
\hline & \multicolumn{4}{c}{ Relative Abundance (\%) } \\
\hline Monoterpene Hydrocarbons (mh) & $61.2 \pm 2.7$ & $60 \pm 2.5$ & $54.7 \pm 4.6$ & $69.6 \pm 4.7$ \\
Oxygenated Monoterpenes (om) & $23.3 \pm 0.7$ & $19.3 \pm 1.5$ & $2.3 \pm 0.83$ & $1.0 \pm 0.1$ \\
Total Monoterpenes (TM) & $\mathbf{8 4 . 5}$ & $\mathbf{7 9 . 3}$ & $\mathbf{5 7 . 0}$ & $\mathbf{7 0 . 6}$ \\
Sesquiterpene Hydrocarbons (sh) & $15.1 \pm 1.7$ & $15.8 \pm 1.0$ & $35.2 \pm 3.9$ & $27.9 \pm 4.7$ \\
Oxygenated Sesquiterpenes (os) & $0.2 \pm 0.0$ & $1.0 \pm 0.0$ & $6.9 \pm 1.6$ & - \\
Total Sesquiterpenes (TS) & $\mathbf{1 5 . 3}$ & $\mathbf{1 6 . 8}$ & $\mathbf{4 2 . 1}$ & $\mathbf{2 7 . 9}$ \\
Diterpene Hydrocarbons (dh) & - & - & - & $1.0 \pm 0.2$ \\
Oxygenated Diterpenes (od) & - & - & - & $0.1 \pm 0.1$ \\
Total Diterpenes (TD) & - & - & $\mathbf{1 . 1}$ \\
Non-terpene Derivatives (nt) & $\mathbf{0 . 2} \pm \mathbf{0 . 2}$ & $\mathbf{3 . 7} \pm \mathbf{0 . 0}$ & $\mathbf{0 . 9} \pm \mathbf{0 . 1}$ & $\mathbf{0 . 4} \pm \mathbf{0 . 2}$ \\
\hline Total Identified (\%) & $\mathbf{1 0 0 . 0 \pm \mathbf { 0 . 0 }}$ & $\mathbf{9 9 . 8} \pm \mathbf{0 . 2}$ & $\mathbf{1 0 0 . 0} \pm \mathbf{0 . 0}$ & $\mathbf{1 0 0 . 0} \pm \mathbf{0 . 0}$ \\
\hline
\end{tabular}

Principal component analysis (PCA) as well as hierarchical cluster analysis (HCA) (Figures 2 and 3) were performed for all compounds present in at least one of the investigated species with a percentage higher than $2 \%$. Taking into consideration the PC1 axis (the direction explaining the maximum variance $(71.5 \%))$, two macro groups were present: one with positive loading along this axis and the other with a negative one. It is important to notice that all the variables are concentrated around the origin of the axes, and only four variables, $\delta$-cadinene, $\alpha$-pinene, sabinene, and $\beta$-thujone, were more dispersed. In particular, these compounds explained the position of each studied Helichrysum in the PCA graph. In fact, the positive loading of $\delta$-cadinene in both axes was responsible for the H. pandurifolium VOC position. H. trilineatum located in the lower case of the graph (negative PC1, positive PC2) owing its position to the high amount in $\alpha$-pinene. The highest amount of sabinene placed $H$. cooperi in the left down quadrant, while $H$. edwardsii was found in the upper case on the left owing to its amount in $\beta$-thujone.

Then, the HCA of the volatile emissions from each Helichrysum species, shown in Figure 2, pointed out an outcome perfectly in agreement with the PCA results. HCA clustered these Helichrysum species in two different groups: A and B, where H. pandurifolium and H. trilineatum made up group A, while group $B$ clustered together the remaining species.

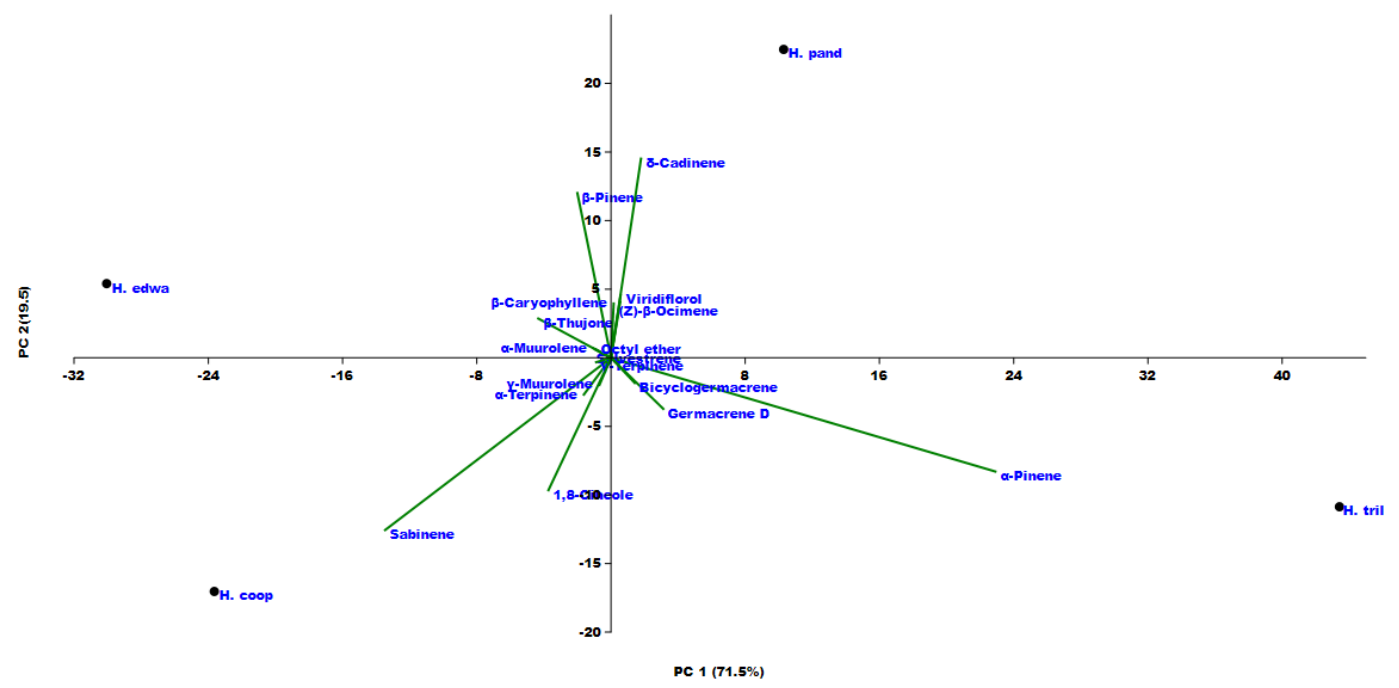

Figure 2. Principal component analysis (PCA) of the VOCs emitted from the investigated Helichrysum species. 


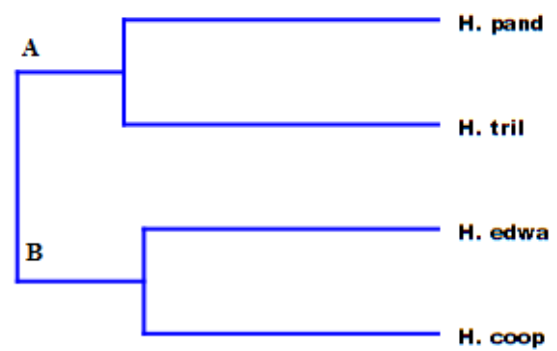

Figure 3. Hierarchical cluster analysis (HCA) of the VOCs emitted from the investigated Helichrysum species.

Only few studies are reported in the literature on the aromatic profile of the Helichrysum species from South Africa. The work of Reidel [20] pointed out a high percentage of sesquiterpene hydrocarbons $(92.9 \%)$ in the flowers of $H$. nudifolium (L.) Less., with $\beta$-caryophyllene as the most abundant constituent $(79.4 \%)$. In the present work, the studied species showed a different behaviour; in fact, the dominant class of compounds was monoterpene hydrocarbons. This comportment did not deny the presence of sesquiterpene compounds especially in $H$. pandurifolium. $\beta$-caryophyllene was also present in all the studied species, but with a lesser amount.

Focusing our attention on the South African species of Helichrysum, recently, Giovanelli [21] and Najar [22] investigated the VOC emissions of the following species: H. cymosum (L.) D.Don, H. odoratissimum (L.) Sweet, H. petiolare Hilliard \& B.L.Burtt and H. tenax M.D.Hend., H.foetidum (L.) Cass., H. incarnatum DC., H. indicum (L.) Grierson, H. montanum DC., H. mutabile Hilliard, H. patulum (L.) D. Don, and H. setosum Harv. More than $45 \%$ of the total volatile composition from all the listed species was done by monoterpene hydrocarbons, with $\alpha$ - and $\beta$-pinene (in H. odoratissimum, H. petiolare, $H$. tenax, $H$. patulum and $H$. setosum), (Z)- $\beta$-ocimene (in $H$. cymosum and $H$. incarnatum), sabinene (H. foetidum), myrcene (H. indicum), triciclene (H. montanum), and limonene (H. mutabile) as the main compounds. The investigated species herein showed a similar behaviour concerning the predominant class of constituents. Except for tricyclene, all the other compounds previously mentioned had been identified, even though with different percentages. H. cooperi such as the already studied H. tenax underlined a high percentage of oxygenated monoterpenes, with the most abundant compound 1,8 -cineole [21].

\subsection{Essential Oils}

The chemical composition of the EOs from the analysed species is reported in Table 3. More than eighty compounds were detected, whose percentages accounted for more than $97 \%$ of the total identified fraction. The highest yield of the extracted oils was found in $H$ cooperi $(0.6 \% w / w)$, while $H$. trilineatum showed the lowest one $(0.1 \mathrm{w} / \mathrm{w})$. Only three compounds were in common in all the studied species: $\alpha$-pinene (whose percentage ranged from $2.3 \%$ in $H$. cooperi to $16.5 \%$ in $H$. odoratissimum), $\beta$-pinene (from $1.5 \%$ in $H$. trilineatum to $31.2 \%$ in $H$. edwardsii), and $\beta$-caryophyllene (from $0.4 \%$ in $H$. trilineatum to $4.1 \%$ in $H$. odoratissimum).

H. pandurifolium, less rich in the number of identified compounds (24), was dominated by the oxygenated sesquiterpenes (os, 74.7\%) (Figure 4, Table 4) mostly represented by viridiflorol (60.3\%). This EO pointed out almost the same amount in sesquiterpene and monoterpene hydrocarbons (11.8\% and $10.3 \%$, respectively) (Figure 4$)$, and showed five exclusive compounds: pogostol $(4.8 \%)$, germacrene D-4-ol (2.5\%), (Z)- $\beta$-ocimene (1.1\%), (E)-1(6,10-dimethylundec-5-en-2-yl)-4-methylbenzene $(1.4 \%)$, and aristolochene $(0.5 \%)$. H. odoratissimun EO evidenced a very close percentage of os, om, and $\mathrm{mh}(28.9 \%, 25.8 \%$, and $23.7 \%$, respectively) with epi-cubebol $(9.0 \%), 1,8$-cineol $(25.1 \%)$, and $\alpha$-pinene (16.5\%) as the most representative compound in each class, respectively. It is fair to report that the exclusive constituents represented $19 \%$ of the identified fraction, where epi-cubebol and 14-hydroxy-9-epi-(E)-caryophyllene (5.0\%) showed the predominant amount. More than 65\% 
of the identified fraction of the EO composition of $H$. edwardsii was represented by monoterpene hydrocarbons $(\mathrm{mh})$ characterized by sabinene $(22.4 \%)$ and $\beta$-pinene $(31.2 \%)$. This latter class was also the main one in $H$. cooperi ( $\mathrm{mh} 37.1 \%)$, where sabinene was also present in a good percentage $(14.7 \%)$. Oxygenated monoterpene (om $31.1 \%$ ) was also in a good amount in this same EO, especially represented by 1,8 -cineol $(16.4 \%)$.

Table 3. Identified compounds in the essential oils of the studied Helichysum spp. (for chromatograms, see Table S2 in Supplementary Materials).

\begin{tabular}{|c|c|c|c|c|c|c|c|c|c|}
\hline & Compounds * & Class & LRI $^{\exp }$ & LRI $^{\text {lit }}$ & H.cooperi & H.edwardsii & H. odoratissimum & H.pandurifolium & H. trilineatum \\
\hline & & & & & \multicolumn{5}{|c|}{ Relative Abundance (\%) } \\
\hline 1 & $\alpha$-thujene & $\mathrm{mh}$ & 930 & 924 & $5.0 \pm 0.4$ & $0.6 \pm 0.0$ & - & - & - \\
\hline 3 & sabinene ${ }^{L}$ & $\mathrm{mh}$ & 975 & 969 & $14.7 \pm 1.2$ & $22.4 \pm 0.1$ & $0.2 \pm 0.1$ & - & - \\
\hline 4 & $\beta$-pinene ${ }^{<}$ & $\mathrm{mh}$ & 979 & 974 & $4.3 \pm 0.1$ & $31.2 \pm 3.1$ & $2.0 \pm 0.0$ & $2.9 \pm 0.1$ & $1.5 \pm 0.2$ \\
\hline 5 & myrcene ${ }^{2}$ & $\mathrm{mh}$ & 991 & 988 & $0.5 \pm 0.0$ & $0.7 \pm 0.0$ & $0.4 \pm 0.2$ & $0.2 \pm 0.0$ & - \\
\hline 6 & $\alpha$-terpinene ${ }^{<}$ & $\mathrm{mh}$ & 1017 & 1014 & $3.6 \pm 0.3$ & $1.0 \pm 0.1$ & $2.2 \pm 0.1$ & - & - \\
\hline 9 & 1,8-cineol ${ }^{<}$ & om & 1031 & 1026 & $16.4 \pm 0.1$ & - & $25.1 \pm 0.9$ & $0.6 \pm 0.3$ & - \\
\hline 10 & (Z)- $\beta$-ocimene & $\mathrm{mh}$ & 1037 & 1032 & - & - & - & $1.1 \pm 0.2$ & - \\
\hline 11 & $\gamma$-terpinene ${ }^{<}$ & $\mathrm{mh}$ & 1060 & 1054 & $4.7 \pm 0.4$ & $1.5 \pm 0.5$ & $1.2 \pm 0.0$ & - & $0.1 \pm 0.1$ \\
\hline 12 & cis-sabinene hydrate ${ }^{<}$ & om & 1070 & 1065 & $2.6 \pm 0.1$ & $0.7 \pm 0.1$ & - & - & - \\
\hline 13 & terpinolene ${ }^{<}$ & $\mathrm{mh}$ & 1089 & 1086 & $1.2 \pm 0.2$ & $0.4 \pm 0.0$ & $0.5 \pm 0.0$ & - & - \\
\hline 14 & trans-sabinene hydrate & om & 1098 & 1098 & $2.3 \pm 0.1$ & $0.5 \pm 0.0$ & - & - & - \\
\hline 19 & pinocarvone & om & 1165 & 1160 & - & $0.5 \pm 0.1$ & - & - & $0.3 \pm 0.0$ \\
\hline 20 & terpinen-4-ol $\angle$ & om & 1177 & 1174 & $8.4 \pm 0.9$ & $3.4 \pm 1.0$ & $0.7 \pm 0.0$ & - & $0.2 \pm 0.0$ \\
\hline 21 & myrtenol & om & 1195 & 1194 & $0.4 \pm 0.0$ & $1.4 \pm 0.4$ & - & - & \\
\hline 22 & $\beta$-bourbonene & $\mathrm{sh}$ & 1388 & 1387 & $0.3 \pm 0.1$ & - & - & - & $0.5 \pm 0.1$ \\
\hline 23 & $\beta$-caryophyllene ${ }^{<}$ & sh & 1419 & 1417 & $0.9 \pm 0.5$ & $1.8 \pm 0.0$ & $4.1 \pm 0.1$ & $1.2 \pm 0.1$ & $0.4 \pm 0.1$ \\
\hline 24 & $\gamma$-elemene & sh & 1433 & 1434 & - & - & - & - & $0.7 \pm 0.6$ \\
\hline 25 & aromadendrene $\angle$ & sh & 1441 & 1439 & $0.2 \pm 0.0$ & - & - & - & $0.9 \pm 0.1$ \\
\hline 26 & $\gamma$-muurolene & sh & 1480 & 1478 & $0.5 \pm 0.0$ & - & $1.8 \pm 0.5$ & - & $0.8 \pm 0.1$ \\
\hline 27 & ar-curcumene & sh & 1481 & 1479 & $1.2 \pm 0.0$ & - & - & - & \\
\hline 28 & germacrene $\mathrm{D}$ & sh & 1485 & 1484 & $3.7 \pm 0.4$ & - & - & - & $5.5 \pm 0.4$ \\
\hline 29 & aristolochene & $\mathrm{sh}$ & 1487 & 1487 & - & - & - & $0.5 \pm 0.0$ & \\
\hline 30 & $\beta$-selienene & sh & 1490 & 1489 & - & - & $8.1 \pm 0.1$ & $0.7 \pm 0.3$ & $0.7 \pm 0.2$ \\
\hline 31 & epi-cubebol & os & 1494 & 1493 & - & - & $9.0 \pm 0.1$ & & \\
\hline 40 & spathulenol & os & 1578 & 1577 & $1.1 \pm 0.2$ & $3.3 \pm 0.3$ & - & $0.3 \pm 0.1$ & $7.2 \pm 0.6$ \\
\hline 41 & caryophyllene oxide ${ }^{<}$ & os & 1583 & 1582 & $1.6 \pm 0.3$ & $4.6 \pm 0.6$ & - & $0.6 \pm 0.3$ & - \\
\hline 42 & globulol & os & 1585 & 1590 & $2.3 \pm 0.5$ & - & $1.1 \pm 0.00$ & - & $1.6 \pm 0.1$ \\
\hline 43 & viridiflorol & os & 1593 & 1592 & - & - & $2.9 \pm 0.14$ & $60.3 \pm 0.8$ & $0.5 \pm 0.1$ \\
\hline 44 & octadienyl tiglate, $2 E, 4 E-$ & nt & 1595 & $1595 !$ & - & - & $2.1 \pm 0.03$ & - & - \\
\hline 45 & rosifoliol & os & 1600 & 1600 & - & - & - & $0.6 \pm 0.0$ & $0.7 \pm 0.3$ \\
\hline 46 & 1-epi-cubenol & os & 1629 & 1627 & - & - & $0.8 \pm 0.01$ & - & - \\
\hline 47 & muurola-4,10(14)- dien- $1 \beta$-ol & os & 1635 & 1630 & - & - & - & $0.8 \pm 0.0$ & $0.5 \pm 0.0$ \\
\hline 48 & $\beta$-acorenol & os & 1636 & 1632 & - & - & $0.5 \pm 0.01$ & - & - \\
\hline 49 & isospathulenol & os & 1638 & $1639^{\$}$ & - & - & - & - & $0.9 \pm 0.1$ \\
\hline 50 & epi- $\alpha$-cadinol & os & 1640 & 1638 & - & - & - & - & $0.8 \pm 0.1$ \\
\hline 51 & $\begin{array}{l}\text { caryophylla-4(14),8(15)- } \\
\text { dien-5-ol }\end{array}$ & os & 1641 & $1639^{\$}$ & - & $0.9 \pm 0.0$ & - & - & - \\
\hline 52 & epi- $\alpha$-muurolol & os & 1642 & 1640 & $0.1 \pm 0.1$ & - & - & $0.5 \pm 0.1$ & - \\
\hline 53 & valerianol & os & 1644 & 1656 & - & $0.5 \pm 0.0$ & - & - & - \\
\hline 54 & $\beta$-eudesmol $<$ & os & 1651 & 1649 & - & $1.0 \pm 0.3$ & - & - & - \\
\hline 55 & $\alpha$-Cadinol & os & 1653 & 1652 & - & - & - & - & $0.9 \pm 0.0$ \\
\hline 56 & pogostol & os & 1655 & 1651 & - & - & & $4.8 \pm 1.8$ & - \\
\hline 57 & himachalol & os & 1657 & 1652 & $6.6 \pm 0.5$ & - & $0.2 \pm 0.0$ & - & $0.7 \pm 0.5$ \\
\hline 58 & selin-11-en- $4 \alpha$-ol & os & 1660 & 1658 & - & - & $0.6 \pm 0.3$ & - & - \\
\hline 59 & intermedeol & os & 1667 & 1665 & $3.0 \pm 0.2$ & - & - & - & - \\
\hline
\end{tabular}


Table 3. Cont.

\begin{tabular}{|c|c|c|c|c|c|c|c|c|c|}
\hline & Compounds * & Class & LRI $^{\exp }$ & LRI $^{\text {lit }}$ & H.cooperi & H.edwardsii & H.odoratissimum & H.pandurifolium & H. trilineatum \\
\hline & & & & & \multicolumn{5}{|c|}{ Relative Abundance (\%) } \\
\hline 60 & $\begin{array}{l}\text { 14-hydroxy-9-epi- } \\
(E) \text {-caryophyllene }\end{array}$ & os & 1670 & 1668 & - & - & $5.0 \pm 0.3$ & - & - \\
\hline 61 & valeranone & os & 1672 & 1674 & - & $1.2 \pm 0.2$ & - & - & - \\
\hline 62 & $\beta$-bisabolol & os & 1675 & 1674 & $0.8 \pm 0.0$ & - & - & - & - \\
\hline 63 & aromadendrene oxide-(2) & os & 1678 & $1678^{\$}$ & - & - & - & $2.9 \pm 0.5$ & $0.3 \pm 0.0$ \\
\hline 64 & epi- $\alpha$-bisabolol & os & 1685 & 1683 & $2.6 \pm 0.6$ & - & $5.6 \pm 0.1$ & - & - \\
\hline 66 & $\begin{array}{l}\text { 14-hydroxy- } \alpha \text {-humulene } \\
\text { 2,4b-dimethyl-8-methylene-2- }\end{array}$ & os & 1713 & 1713 & - & - & $1.4 \pm 0.4$ & - & - \\
\hline & $\begin{array}{l}\text { vinyl-1,2,3,4,4a,4b,5,6,7,8,8a,9- } \\
\text { dodecahydrophenanthrene }\end{array}$ & $\mathrm{nt}$ & 1842 & $1858 *$ & - & - & - & - & $0.6 \pm 0.2$ \\
\hline 68 & beyerene & $\mathrm{dh}$ & 1943 & $1951^{\$}$ & - & - & - & - & $1.0 \pm 0.2$ \\
\hline 69 & $\begin{array}{l}\text { (E)-1(6,10-dimethylundec-5-en- } \\
\text { 2-yl)-4-methylbenzene }\end{array}$ & $\mathrm{pp}$ & 1951 & $1950^{\$}$ & - & - & - & $1.4 \pm 0.1$ & - \\
\hline 73 & abieta-7,13-diene & $\mathrm{dh}$ & 2080 & $2088^{\$}$ & - & - & - & - & $6.1 \pm 0.9$ \\
\hline 74 & sandaracopimarinal & od & 2214 & 2184 & - & - & - & - & $1.2 \pm 0.2$ \\
\hline 75 & sclareol $<$ & od & 2227 & 2222 & - & - & - & - & $0.6 \pm 0.1$ \\
\hline 76 & pimara-7,15-dien-3-ol & od & 2253 & $2253^{\$}$ & - & - & - & - & $0.6 \pm 0.1$ \\
\hline 77 & larixol & od & 2264 & 2265 & - & - & - & - & $0.6 \pm 0.1$ \\
\hline 78 & sandaracopimarinol & od & 2279 & 2269 & - & - & - & - & $17.7 \pm 2.3$ \\
\hline 79 & neoabietal & od & 2320 & $2299^{\$}$ & - & - & - & - & $1.3 \pm 0.2$ \\
\hline 80 & neoabietic acid & od & 2335 & $2335^{\$}$ & - & - & - & - & $2.1 \pm 0.4$ \\
\hline 81 & abietinol & od & 2391 & $2389^{\$}$ & - & - & - & - & $1.2 \pm 0.2$ \\
\hline & $\mathbf{N}^{\circ}$ of Identified Peaks & & & & 32 & 26 & 27 & 24 & 43 \\
\hline & EO Yield $(\% w / w)$ & & & & $0.60 \pm 0.0$ & $0.57 \pm 0.4$ & $0.45 \pm 0.0$ & $0.48 \pm 0.1$ & $0.1 \pm 0.0$ \\
\hline
\end{tabular}

* Compounds present with percentage $\geq 1 \%$ in at least one of the Helichrysum spp. Data are reported as mean values $(n=3 \pm \mathrm{SD})$; EO, essential oil; L.R.I. ${ }^{\text {exp }}$, linear retention time experimentally determined; L.R.I. ${ }^{\text {lit }}$, linear retention time reported by Adams 2007; ${ }^{\$}$ linear retention time reported by NIST 2014; ${ }^{*}$ linear retention index in chemspider (www.chemspider.com); ! linear retention time reported by Adams and Dev 2010 [23]. ' compounds identified by comparison to injected authentic reference samples purchased from Sigma-Aldrich, Inc. Bold format: Main constituents.

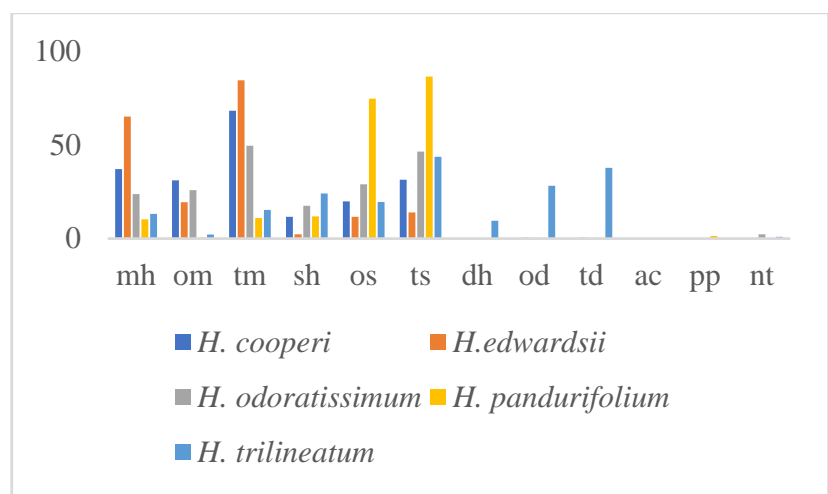

Figure 4. Variation of the class of compounds in the essential oils (EOs) of the studied Helichrysum spp. mh: monoterpenes hydrocarbons; om: oxygenated monoterpenes; tm: total monoterpenes; sh: sesquiterpene hydrocarbons; os: oxygenated sesquiterpenes; ts: total sesquiterpenes; dh: diterpene hydrocarbons; od: oxygenated diterpenes; td total diterpenes; nt: non-terpene derivatives.

The exclusivity in a high amount of both trans and cis thujone (8.7\% and $1.3 \%$, respectively) in H. edwardsii is noteworthy.

H. trilineatum EO accounts for the greatest number of constituents (43) (Table 3), showing a composition dominated by oxygenated diterpenes (od, 28.2\%), with the main compound being sandaracopimarinol (17.7\%), a peculiar compound of this species. Followed by a high percentage of sesquiterpene hydrocarbons $(24.1 \%)$ characterized by bicyclogermacrene $(10.7 \%)$ and germacrene D $(5.5 \%)$, together with oxygenated sesquiterpenes $(19.5 \%)$, with spatulenol $(7.2 \%)$ as the most abundant one. Monoterpene hydrocarbons, which represented $13.2 \%$ of the total identified compounds, were also 
present with $\alpha$-pinene (11.5\%) as a major constituent. Abieta-7,13-diene (6.1\%) was indeed the most important compound of the diterpene hydrocarbons, which represented $9.5 \%$ of the total composition.

Table 4. Class of compounds in the essential oil of the studied Helichysum spp.

\begin{tabular}{|c|c|c|c|c|c|}
\hline Chemical Classes & H. cooperi & H.edwardsii & H. odoratissimum & H. pandurifolium & H. trilineatum \\
\hline & \multicolumn{5}{|c|}{ Relative Abundance (\%) } \\
\hline Monoterpene Hydrocarbons (mh) & $37.1 \pm 1.2$ & $65.1 \pm 2.4$ & $23.7 \pm 1.0$ & $10.3 \pm 0.4$ & $13.2 \pm 3.4$ \\
\hline Oxygenated Monoterpenes (om) & $31.1 \pm 0.8$ & $19.4 \pm 0.6$ & $25.8 \pm 2.0$ & $0.6 \pm 0.4$ & $2.1 \pm 0.1$ \\
\hline Total Monoterpenes (TM) & 68.2 & 84.5 & 49.5 & 10.9 & 15.3 \\
\hline Sesquiterpene Hydrocarbons (sh) & $11.6 \pm 0.9$ & $2.3 \pm 0.2$ & $17.5 \pm 0.3$ & $11.8 \pm 0.4$ & $24.1 \pm 0.9$ \\
\hline Oxygenated Sesquiterpenes (os) & $19.8 \pm 0.5$ & $11.6 \pm 1.0$ & $28.9 \pm 1.6$ & $74.7 \pm 0.8$ & $19.5 \pm 3.5$ \\
\hline Total Sesquiterpenes & 31.4 & 13.9 & 46.4 & 86.5 & 43.6 \\
\hline Diterpene Hydrocarbons (dh) & - & - & - & - & $9.5 \pm 1.6$ \\
\hline Oxygenated Diterpenes (od) & - & $0.5 \pm 0.0$ & - & $0.4 \pm 0.1$ & $28.2 \pm 3.2$ \\
\hline Total Diterpenes & - & 0.5 & - & 0.4 & 37.7 \\
\hline Apocarotenoids (ac) & - & - & - & - & $0.2 \pm 0.1$ \\
\hline Phenylpropanoids (pp) & - & - & - & $1.4 \pm 0.1$ & - \\
\hline Non-terpene Derivatives (nt) & - & - & $2.1 \pm 0.0$ & $0.3 \pm 0.1$ & $0.9 \pm 0.2$ \\
\hline Total Identified (\%) & $99.6 \pm 0.4$ & $98.9 \pm 1.1$ & $98.0 \pm 2.0$ & $99.5 \pm 0.5$ & $97.7 \pm 2.3$ \\
\hline
\end{tabular}

PCA and HCA statistical analyses were performed using the compounds present in amounts greater than $5 \%$ for at least one of the studied species (Figures 5 and 6). The upper right quadrant of PCA analysis (Figure 5) included exclusively H. pandurifolium, whose main component was viridiflorol. H. edwardsii was located in the upper left quadrant, because of their higher percentages in both $\beta$-pinene and sabinene, compounds lading negatively with PC2. All the others species were in the lower left quadrant (PC 1 negative and PC 2 negative).

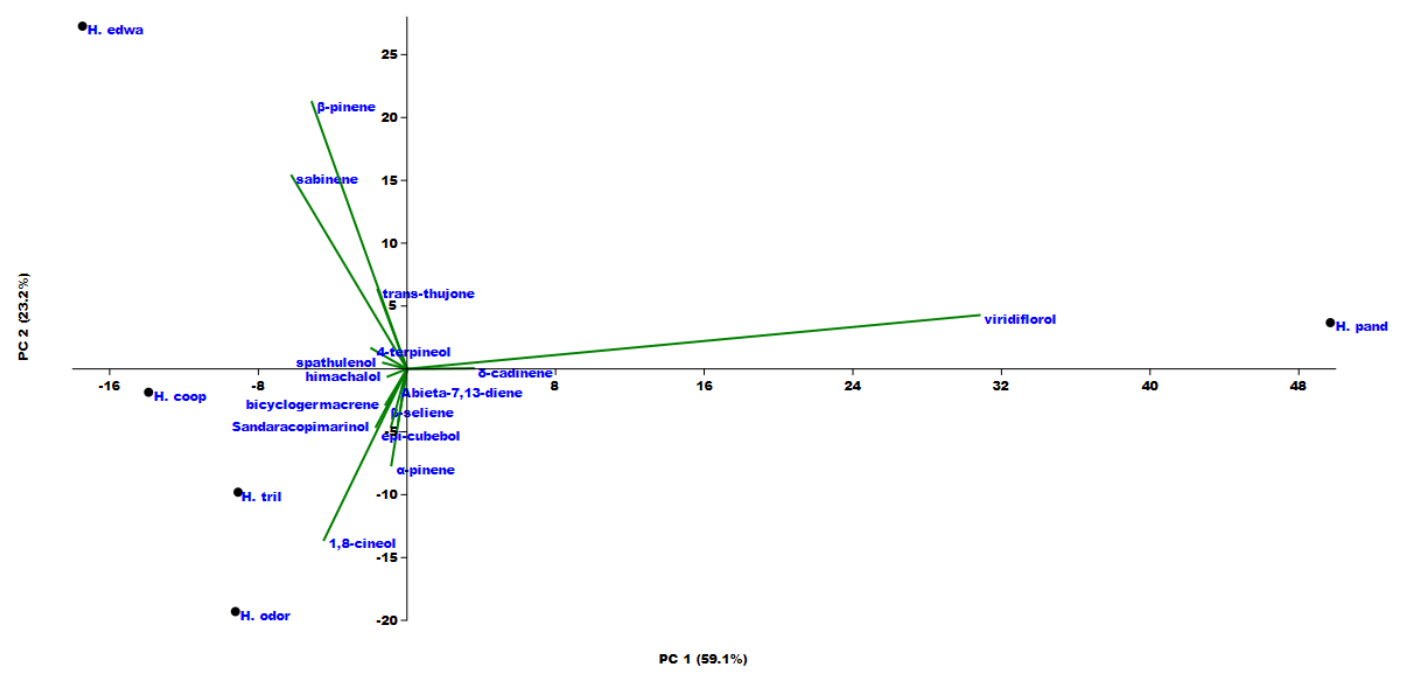

Figure 5. Principal component analysis of the EOs from the studied species of Helichrysum.

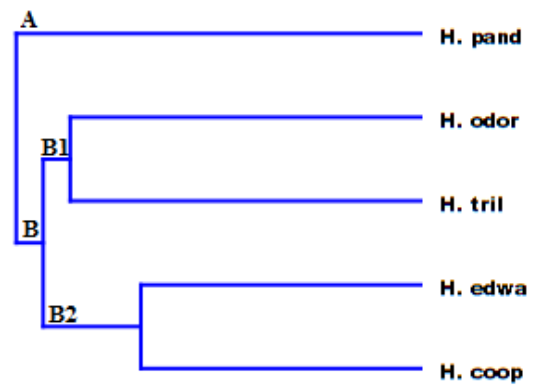

Figure 6. Hierarchical cluster analysis of the EOs obtained from all the studied species of Helichrysum. 
The dendrogram obtained from HCA, reported in Figure 6, was in accordance with the results of PCA and distinguished $H$. pandurifolium from all the other Helichrysum species located in group A. The group B consists of two subgroups (B1 and B2). B1 included H. trilineatum with H. odoratissimum, while subgroup B2 clustered together the remaining species.

Although numerous reports in the literature deal with the chemical composition of the EOs from different species of Helichrysum.

Regarding the EO composition of H. odoratissimum, the first studies date back to 1993 when both Gundidza and Zwaving [23] and Lwande [24] reported $\alpha$-pinene and $\alpha$-humulene as main constituents. Later on, Kuiate and coworkers [25] found EO rich in $\alpha$-pinene (41.0-47.0\%), $\beta$-caryophyllene (5.0-14.0\%), and $\alpha$-curcumene (4.0-20.0\%), while limonene (23.0-32.0\%), $\beta$-caryophyllene (12.0-13.0\%), and $\alpha$-pinene (8.0-10.0\%) characterized the EO analysed by Asekun [14]. Except for $\alpha$-curcumene and $\alpha$-humulene, all the other compounds were present in a good amount in the studied H. odoratissimum EO. A more recent paper on the EO of the same species [17] pointed out $\beta$-pinene (51.6\%), limonene (16.9\%), $\alpha$-humulene $(5.6 \%)$, and $\beta$-caryophyllene $(4.7 \%)$ as major constituents. Limonene was completely absent in the EO studied herein against a high amount in 1,8-cineole. Concerning b-caryophyllene, our result was in agreement with what was found by these latter cited authors.

Cavalli [26] characterized the EOs of six Madagascarian species of Helichrysum: H. gymnocephalum (DC.) Humbert, H. bracteiferum (DC.) Humbert, H. selaginifolium (DC.) Viguier \& Humbert, H. cordifolium DC., H. faradifani Scott-Elliot, and H. hypnoides (DC.) Viguier \& Humbert. The main compounds evidenced were 1,8-cineole (59.7\% in H. gymnocephalum and $27.3 \%$ in H. bracteiferum), $\beta$-pinene (38.2\% in H. selaginifolium), and $\beta$-caryophyllene (55.6\% in H. cordifolium, 34.6\% in H. faradifani, and $34.0 \%$ in H. hypnoides).

The EO composition of South African H. dasyanthum (Willd.) Sweet, H. excisum (Thunb.) Less., $H$. petiolare Hilliard \& B.L.Burtt, and H. felinum Less. was analysed by Lourens [10]. In the first three species, 1,8-cineol (20.0-34.0\%), $\alpha$-pinene (3.0-17.0\%), and $p$-cymene predominated (6.0-10.0\%), while $\beta$-caryophyllene (27.6\%), $\alpha$-humulene (9.4\%), and caryophyllene oxide (6.9\%) were the most abundant in H. felinum EO. Viridiflorol was present in a good amount (18.2\%) only in H. excisum.

Previous investigations on other Helichrysum species from South Africa were done by our research group and, among these, Bandeira Reidel evidenced $\beta$-caryophyllene as the most abundant compound (46.0\%) in H. nudifolium (L.) Less. [20]. More recently, Najar studied other eight species [22]. Except for $H$. incarnatum where monoterpene hydrocarbons prevailed $(60.7 \%)$, mostly represented by (Z)- $\beta$-ocimene (17.0\%), $\beta$-phellandrene (12\%), and $\alpha$-pinene $(11.6 \%)$, and all the other species highlighted a high percentage of sesquiterpene compounds. Valerianol (in H. basalticum Hilliard, H. foetidum (L.) Cass. and H. setosum Harv), viridiflorol (H. foetidum (L.) Cass. and H. montanum DC), $\beta$-caryophyllene (H. indicum (L.) Grierson and H. patulum (L.) D.Don), sandaracopimarinol (in H. mutabile Hilliard), $\beta$-himachelene, caryophyllene oxide (H. montanum DC.,), $\delta$-cadinene (H. montanum DC), aromadendrene, and globulol (H. basalticum Hilliard) were the main constituents. Among all the compounds identified in the previous South African species, only four of them showed more than $10 \%$ of the identified fraction of the analysed species in this work. These constituents were 1,8 -cineole (in H. cooperi and H. odoratissimum), $\alpha$-pinene (in H. odoratissimum and $H$. trilineatum), viridiflorol (H. pandorifolum), and sandaracopimarinol (H. trilineatum).

$\beta$-caryophyllene seemed to be one of the peculiar compounds in the EO of Helichrysum spp. This constituent was also present, in variable percentages, in all our EOs.

\subsection{Antimicrobial Activity}

The antimicrobial analyses were performed in all the studied species, together with two further species (H. foetidum and H. patulum) whose composition was reported in our previous study [22]. The results of the tests are reported in Tables 5 and 6. 
Table 5. Antifungal activity (in \%) of the tested essential oils (EOs) of Helichrysum species.

\begin{tabular}{|c|c|c|c|c|c|c|}
\hline & & \multicolumn{2}{|c|}{ Dermatophytes } & \multicolumn{2}{|c|}{ Aspergillus } & \multirow{2}{*}{$\begin{array}{c}\text { Fusarium } \\
\text { F. solani }\end{array}$} \\
\hline & & M. canis & T. mentagrophytes & A. flavus & A. niger & \\
\hline \multirow{5}{*}{$\begin{array}{l}\text { Present } \\
\text { study }\end{array}$} & H. cooperi & 0.5 & 1 & $>5$ & $>5$ & $>5$ \\
\hline & H. edwardsii & 0.25 & 1 & $>5$ & $>5$ & $>5$ \\
\hline & H. odoratissimum & $>5$ & $>5$ & $>5$ & $>5$ & $>5$ \\
\hline & H. pandurifolium & 0.25 & 0.5 & 5 & $>5$ & 5 \\
\hline & H. trilineatum & 5 & 5 & 5 & $>5$ & 5 \\
\hline \multirow{2}{*}{$\begin{array}{l}\text { Previous } \\
\text { study * }\end{array}$} & H. foetidum & $>5$ & $>5$ & $>5$ & $>5$ & $>5$ \\
\hline & H. patulum & 5 & 5 & $>5$ & $>5$ & $>5$ \\
\hline
\end{tabular}

Table 6. Antibacterial activity of the tested EOs of Helichrysum species. MIC, minimum inhibitory concentration.

\begin{tabular}{cccccc}
\hline & \multicolumn{2}{c}{ S. aureus } & \multicolumn{2}{c}{ S. pseudointermedius } \\
\hline \multirow{3}{*}{ Present study } & Disk $(\mathbf{m m})$ & MIC (\%) & Disk (mm) & MIC (\%) \\
& H. cooperi & 0 & $>10$ & 0 & $>10$ \\
& H. edwardsii & 0 & $>10$ & 7 & 10 \\
& H. odoratissimum & 0 & $>10$ & 0 & $>10$ \\
& H. pandurifolium & 7 & 5 & 8 & 5 \\
& H. trilineatum & 7 & 5 & 8 & 5 \\
\hline \multirow{2}{*}{ Previous study * } & H. foetidum & 0 & $>10$ & 0 & $>10$ \\
& H. patulum & 0 & $>10$ & 0 & $>10$ \\
\hline
\end{tabular}

${ }^{*}$ Reference list number [22].

Dermatophytes were more sensitive to some EOs in comparison with environmental fungi, where no inhibition of their growth was noticed. M. canis was the most sensitive fungal species especially to $H$. pandurifolium, $H$. trilineatum, and $H$. edwardsii EOs, with the lowest values of minimum inhibitory concentration (MIC) $(0.25 \%)$. These oils were active on T. mentagrophytes also (MIC value of $0.5 \%$ and $1 \%$ for the latter, respectively). Moreover, $H$. cooperi showed a not negligible action on $M$. canis (MIC $0.5 \%$ ). It was not possible to set an MIC value for H. patulum EO owing to its very low yield. The amount obtained allowed us to test its antifungal activity only with an initial dilution of $5 \%$, to which both dermatophytes have been shown to be sensitive. All dermatophytes were sensitive to itraconazole $(8 \mu \mathrm{g} / \mathrm{mL})$, while other fungi scored sensitive to amphotericin B (range: 0.015-8 mg/L).

Both Kirby-Bauer and microdilution methods highlighted that Staphylococcus aureus and Staphylococcus pseudointermedius were mostly sensitive to $H$. pandurifolium and $H$. trilineatum EOs.

H. edwardsii EO produced a growth inhibition zone of $7 \mathrm{~mm}$ diameter and an MIC value of $10 \%$ against S. pseudointermedius, but it was not active versus S. aureus. H cooperi and H odoratissimum did not show anti staphylococcal activity. Both S. aureus and S. pseudointermedius were sensitive to chloramphenicol (growth inhibition zone of $21 \mathrm{~mm}$ in disk diffusion, $8 \mu \mathrm{g} / \mathrm{mL}$ in microdilution method).

The antimicrobial activity of the EOs extracted from endemic plants that grow spontaneously in South Africa was previously investigated [10-13,18,19]. To the best of our knowledge, the antimicrobial activity of the species studied herein is reported for the first time, except for $H$. foetidum and H. odoratissimum. The EO of this latter species grown in South Africa was tested by Lawal [17] and he emphasized the powerful antibacterial action on S. aureus (ATCC 3983) and S. aureus (ATCC 6538), with MIC of 1.3 and $2.5 \mathrm{mg} / \mathrm{mL}$, respectively. Not much convergence between our results and those previously reported is noted, which could be owing to the differences in the EO compositions. The studied species was rich in 1,8-cineole rather than limonene (case of Lawal), which was previously reported to be less active [27-29]. 
The biological activity of $H$. foetidum was studied by Samie [15-31] and reported in the review of Maroyi [32]. Although the authors did not investigate the EO composition, they described its antifungal and antibacterial activities (MIC value on S. aureus $>7.5 \mathrm{mg} / \mathrm{mL}$ ). This result was in agreement with our assay.

H. trilineatum exhibited a moderate action on both bacterial strains and fungi studied herein and, even though it had an equal amount of spathulenol such as in Tanzanian H. fulgidum [33], endowed significant antibacterial activities, and a good percentage of both bicyclogermacrene and germacrene D; likewise in H. splendidum collected in Mpumalanga (South Africa) rich in the cited constituents (range of 7.41-20.5\% and 11.1-26.5\%, respectively), which evidenced a good antifungal activity [18]. Actually, the antibacterial action of this EO could be owing to the presence of sandaracopimarionol, as the purified compound showed a strong antibacterial activity [34].

H. rugulosum, widely collected in South Africa, was investigated for its EO composition and biological activity [11]. The authors ascribed the antibacterial properties of its EO to the high percentage of caryophyllene oxide ( $8.8 \%$ ) and viridiflorol (3.7\%), with an MIC value on S. aureus of $0.38 \mathrm{mg} / \mathrm{mL}$. Other plant species rich in this latter compound evidenced a potent antibacterial activity on $S$. aureus such as Eugenia umbelliflora (viridiflorol, 17.7\%) with MIC $=0.119 \mathrm{mg} / \mathrm{mL}$ [35] and Salvia officinalis (viridiflorol, 10.93\%) (MIC $=0.2 \mathrm{mg} / \mathrm{mL})$ [36]. Fungi were more sensitive to the H. pandurifolim EO rather than bacteria. This oil was mostly composed by viridiflorol (more than the half of identified fraction). As no study investigated the antifungal effect of this latter compound, the activity shown by the use of $H$. pandurifolim EO might owing to the synergic effect of the whole constituents, even those present in a lesser amount. In fact, several compounds associated with several EOs demonstrating good antifungal activities are reported in the literature such as $\beta$-pinene, spathulenol, $\delta$-cadinene, and epi- $\alpha$-muurolol [37-40]. The sensitivity of fungi rather than bacteria was registered again using the $H$. cooperi EO. This activity could be owing to the presence of a good amount of terpinen-4-ol [41] and himachalol [42]. H. edwardsii EO had a varying degree of effectiveness, with Aspergillus and Fusarium being relatively more resistant when compared with dermatophytes. This result was confirmed by the work of Abu-Darwish [43]. The richness in thujone of this oil could explain its effectiveness against dermatophytes, even though several works reported it was active on both bacteria and fungi [44,45].

\section{Materials and Methods}

\subsection{Plant Materials}

All the studied plants, originating from South Africa (Table 7), belong to the collection of the Research units for floriculture and ornamental species of aromatic plants (CREA) located in Sanremo, Italy. The seeds were purchased from specialized companies in sailing seeds of African plant species (Silver Hill-PO Box 53108, Kenilworth, 7745 Cape Town, South Africa and B \& T World Seeds-Paguignan, 34210 Aigues Vives, France). The plants were grown in pots under the same edaphic substrate (perlite (2:1 $v / v$ added with $4 \mathrm{~g} / \mathrm{L}$ slow release fertilizer) and climatic conditions (Csa in Köppen-Geiger climate classification with an average annual temperature of $16^{\circ} \mathrm{C}$ and an annual rainfall of about $700 \mathrm{~mm}$; frosts are light and very rare). After clonal propagation, the plants grew in pots in the open air and were periodically watered. Flowering took place after one year. A voucher sample of each plant was deposited at the herbarium of the Hanbury Botanical Gardens (La Mortola-Ventimiglia, Imperia, Italy). The correct identification of the plants was performed by one of the authors, Claudio Cervelli.

The aerial parts were collected during the flowering period and were dried at room temperature for 5 days up to constant weight. H. cooperi, H. edwardsii, and H. odoratissimum were collected in 2018, while $H$. pandurifolium and $H$. trilineatum were collected in 2019. 
Table 7. Botanical characteristics and traditional medicinal use of the investigated species of Helichrysum.

\begin{tabular}{|c|c|c|}
\hline Studied Species & Photo & Botanical Characteristics and Folk Uses \\
\hline H. cooperi Harv. & & $\begin{array}{l}\text { Voucher } \mathrm{N}^{\circ} \text { : HMGBH.e/9006.2019.002 } \\
\text { General information } \\
\text { - It prefers the prairies and the woods border } \\
\text { - Green, simple, oblong leaves with entire margin and evident vein, } \\
\text { covered by a fine sticky fuzz. } \\
\text { - The fresh leaves have a strong aromatic smell. } \\
\text { - The flower heads are golden yellow placed in a large inflorescence. } \\
\text { Use in traditional African medicine } \\
\text { Leaves are used as a fumigant and as part of snake bite remedy [2]. }\end{array}$ \\
\hline H. edwardsii Wild & & $\begin{array}{l}\text { Voucher } \mathbf{N}^{\circ} \text { : HMGBH.e/9006.2017.002 } \\
\text { General information } \\
\text { - It is a high suffrutice plant, which reaches more than } 1 \mathrm{~m} \text { higher } \\
\text { - } \quad \text { Robust, woody stems. } \\
\text { - The leaves are oblong or ovate, with the surface covered with } \\
\text { glandular hairs. } \\
\text { - } \quad \text { Globular flower heads are gathered in a corymb inflorescence. } \\
\text { Use in traditional African medicine } \\
\text { Leaves are used as a fumigant and as part of snake bite remedy }\end{array}$ \\
\hline $\begin{array}{l}\text { H. odoratissimum (L.) } \\
\text { Sweet }\end{array}$ & & $\begin{array}{l}\text { Voucher } \mathbf{N}^{\circ}: \text { HMGBH.e/9006.2019.007 } \\
\text { General information } \\
\text { - It is widespread in the highlands, mountains, and coastal areas, } \\
\text { particularly on grassy and rocky slopes. } \\
\text { - The stems are thin and fluffy. } \\
\text { - Grey-white leaves can be oblong, lanceolate, ligulated, or spatulate, with } \\
\text { generally obtuse apex. } \\
\text { The flower heads are yellow, small, numerous, and gathered in terminal } \\
\text { corymbs carried by a bare peduncle. } \\
\text { - The fruits are opaque brown. } \\
\text { - Flowering occurs mainly from August to December in the south-west of } \\
\text { the Cape Province and from January to June in the other South } \\
\text { African regions } \\
\text { Use in traditional African medicine } \\
\text { Leaf infusions and decoctions are used to treat fever, insomnia, colic, menstrual } \\
\text { pain, and sterility in women; root extracts are used as purgatives; while leaf } \\
\text { extracts are used as eye drops to treat conjunctivitis [2]. }\end{array}$ \\
\hline $\begin{array}{c}\text { H. pandurifolium } \\
\text { Schrank (= } \\
\text { H. auriculatum Less.) }\end{array}$ & & $\begin{array}{l}\text { Voucher } \mathbf{N}^{\circ} \text { : HMGBH.e/9006.2018.004 } \\
\text { General information } \\
\text { - Grows in sandy or rocky areas, from sea level up to } 1500 \mathrm{~m} \text { of altitude. } \\
\text { - The stems are long, thin, slightly grey, and with a woolly pubescence. } \\
\text { - Orbicular or ovate grey and woolly leaves have a sinuous margin, } \\
\text { and shrink abruptly to form a narrow and curved base similar to a petiole. } \\
\text { - The yellow flower heads are gathered in terminal corymbs. The involucre } \\
\text { bracts are imbricate, sometimes light brown outside; the inner ones are } \\
\text { white-pink and with a sharp apex and exceed the flowers in length. } \\
\text { - The fruits are achenes, which carry a pappus with many feathery bristles. } \\
\text { - Flowering occurs between September and January } \\
\text { Use in traditional African medicine } \\
\text { Infusions and ointments obtained from the aerial parts are used to treat } \\
\text { respiratory and heart problems, back pain, and kidney stones [2]. }\end{array}$ \\
\hline H. trilineatum DC. & & $\begin{array}{l}\text { Voucher } \mathbf{N}^{\circ} \text { : HMGBH.e/9006.2019.006 } \\
\text { General information } \\
\text { - Rocky outcrops of the steep mountain slopes and on the highlands. } \\
\text { - Tomentose and grey-white stems. } \\
\text { - Sessile, linear or oblong leaves, with mucronate and curved apex and } \\
\text { revolute margins. The upper face is dotted with secretory glands, } \\
\text { the lower face is white and woolly and crossed by parallel veins. } \\
\text { - The yellow flower heads, gathered in terminal corymbs. } \\
\text { - Flowering occurs between August and February. The involucre bracts are } \\
\text { imbricate, of golden brown colour on the outside and intense yellow on } \\
\text { the inside. } \\
\text { - The fruits are achenes of } 1 \text { mm long ending in a silky pappus. } \\
\text { Use in traditional African medicine } \\
\text { chloroform extract is active against Staphylococcus aureus [46]. }\end{array}$ \\
\hline
\end{tabular}




\subsection{Chemical Investigation}

\subsubsection{Spontaneous Emission Analysis and EO Extraction}

Living fresh plant material $(1 \mathrm{~g})$ of each species, maintained in pots, was sent from Sanremo (CREA) to Pisa (Dipartimento di Farmacia, University of Pisa, Pisa, Italy) and was maintained in a greenhouse for 2-3 days before SPME analysis. The HS-SPME (head space-solid phase microextraction) analyses were performed using $100 \mu \mathrm{m}$ polydimethylsiloxanes (PDMS) fibre manufactured by Supelco Ltd. (Bellefonte, PA, USA). Prior to the analyses, the fibre was conditioned according to the manufacturer's instruction, at $250{ }^{\circ} \mathrm{C}$ for $30 \mathrm{~min}$ in the injector of a gas chromatograph. The refined material, with a weight of $3.00 \pm 0.01 \mathrm{~g}$, was placed in a $50 \mathrm{~mL}$ glass vial and sealed with an aluminum cap for $60 \mathrm{~min}$ (equilibration time). Exposition of the fibre in the headspace phase of the samples took place for 15 to $30 \mathrm{~min}$ at a temperature of $23^{\circ} \mathrm{C}$. Subsequently, the fibre was transferred to the injector of the gas chromatograph (temperature $250^{\circ} \mathrm{C}$ ), where the analytes were thermally desorbed [47]. The composition of the compounds desorbed from SPME fibre was examined using GC-MS. As no fresh living plant of $H$. odoratissimum was available, it was impossible to carry out the analysis on its spontaneous emission.

The hydrodistillation was used to extract the essential oils from the dried aerial parts $(50 \pm 0.1 \mathrm{~g})$ of each species using a Clevenger apparatus for $2 \mathrm{~h}$ at $100^{\circ} \mathrm{C}$, according to the method reported in the European Pharmacopoeia [48]. The obtained oils were maintained in freezer at $4{ }^{\circ} \mathrm{C}$ and far from light sources until their analyses.

\subsubsection{GC-MS Analysis}

Gas chromatography-electron ionization mass spectrometry (GC-EIMS) analyses were performed with a Varian CP-3800 apparatus equipped with a DB-5 capillary column $(30 \mathrm{~m} \times 0.25 \mathrm{~mm}$ i.d., film thickness $0.25 \mu \mathrm{m}$ ) and a Varian Saturn 2000 ion-trap mass detector. Analytical conditions were as follows: the oven temperature was programmed rising from $60{ }^{\circ} \mathrm{C}$ to $240{ }^{\circ} \mathrm{C}$ at $3{ }^{\circ} \mathrm{C} / \mathrm{min}$; injector temperature $220^{\circ} \mathrm{C}$; transfer-line temperature $240^{\circ} \mathrm{C}$; carrier gas helium He (at $1 \mathrm{~mL} / \mathrm{min}$ ); injection of $1 \mu \mathrm{L}$ ( $5 \%$ HPLC grade $n$-hexane solution); and split ratio 1:30. The acquisition parameters were as follows: full scan; scan range: $35-400 \mathrm{amu}$; and scan time: $1.0 \mathrm{~s}$. Identification of the constituents was based on a comparison of (i) their retention times $\left(t_{R}\right)$ with those of the authentic samples and (ii) their linear retention indices (LRIs), determined relative to the $t_{R}$ of the series of $n$-alkanes, and mass spectra with those listed in the commercial libraries (NIST 14 and ADAMS 2007) and laboratory-developed mass spectra library built up from pure substances and components of known oils and MS literature data [49-54].

\subsection{Antimicrobial Investigation}

\subsubsection{Antimycotic Activity}

Antimycotic activity testing was carried out both on environmental potentially toxigenic molds and on pathogenic clinical isolates. In detail, isolates of Aspergillus niger, Aspergillus flavus, and Fusarium solani, respectively, were used. The molds were cultured from animal feedstuff.

For dermatophyte testing, clinical isolates of Microsporum canis and Trichophyton mentagrophytes, respectively, cultured from cats affected by ringworm, were employed.

All the fungal isolates were maintained onto malt extract agar (MEA) at $25^{\circ} \mathrm{C}$ and identification was accomplished on the basis of their macro and microscopical morphological features.

The antimycotic activity of the selected EOs was evaluated by a microdilution test, carried out as recommended by the Clinical and Laboratory Standards Institute (CLSI) M38-A2 for molds (2008) [CLSI Reference Method for Broth Dilution Antifungal Susceptibility Testing of Filamentous Fungi. 2nd ed. CLSI; Wayne, PA, USA: 2008. approved 541 standards. CLSI document M38-A2.], with slight modification, starting from a $5 \%$ dilution. Five percent, $2.5 \%, 2 \%, 1.5 \%, 1 \%, 0.5 \%, 0.25 \%$, and $0.1 \%$ 
dilutions in semisolid medium were achieved. All the assays were performed in triplicate. Positive and negative controls (with conventional drugs such as itraconazole and amphotericin B and with the medium without EOs) were achieved.

\subsubsection{Antibacterial Activity}

The EOs were assayed against two clinical strains, one of Staphylococcus aureus and one of Staphylococcus pseudointermedius. Both isolates have been previously cultured from canine cutaneous specimens, typed, and stored at $-80{ }^{\circ} \mathrm{C}$ in glycerol broth.

The antibacterial activity of the selected EOs, diluted at $10 \%$ in dimethyl sulfoxide (DMSO, Oxoid LTD Basingstoke, Hampshire, England), was tested by the Kirby-Bauer agar disc diffusion method [55]. A commercial disk impregnated with chloramphenicol (30 $\mu \mathrm{g})$ (Oxoid) and a paper disk impregnated with $10 \mu \mathrm{l}$ of DMSO were included as positive and negative controls, respectively. All tests were performed in triplicate.

The minimum inhibitory concentration (MIC) was determined for all EOs; for this purpose, the broth microdilution method was executed following the guidelines described by the Clinical and Laboratory Standard Institute [56], with some modifications as previously reported [57].

\subsection{Statistical Analysis}

The multivariate statistical analyses were carried out with the Past 3 software package' ver. 3.14. The statistical analysis was done on each VOC and EO composition. The principal component analysis (PCA) was performed selecting the two highest principal components (PCs) of a variance/covariance matrix, methods aimed at reducing the dimensionality of the multivariate data of the matrices, while preserving most of the variance [58]. The hierarchical cluster analysis (HCA) was performed using paired group (UPGMA) algorithm and Bray-Curtis as a similarity index for both the headspace analyses and the EO contents. It is a method in which samples are considered as lying in an n-dimensional space and distances between samples are calculated, joining the object with an agglomerative procedure.

The obtained results were subjected to multivariate statistical analysis using the Past 3.14 software. Hierarchical cluster analysis (HCA) was performed with UPGMA paired group algorithm and Euclidean similarity index, while a variance and covariance matrix was used for principal component analysis (PCA).

\section{Conclusions}

The aim of this study was mainly to introduce these plants in our environment for ornamental purposes owing to the showy habitus of their architectures; moreover, as they were rich in essential oils with a pleasant odour, they may be very appreciated for their possible industrial and cosmetic applications. The chemical composition of five South African Helichrysum species, of which four were studied here for the first time, along with their antimicrobial activity, were reported on. The essential oils of $H$. edwardsii and H. pandurifolium displayed a noteworthy activity on the selected dermatophyte species. A good antibacterial action was also observed using $H$. pandurifolium and H. trilineatum. These EOs can be considered as good candidates for further investigations on their single compounds, seeing that the EO biological activity is strictly related to its chemical composition and to the possible synergistic effects among its components.

Supplementary Materials: The following are available online, Table S1: VOC chromatograms of the studied Helichrysum spp. with the main compounds. Table S2: EO chromatograms of the studied Helichrysum spp. with the main compounds.

Author Contributions: Conceptualization, L.P., B.N., C.C., F.M., and V.V.E.; Methodology, L.P., B.N., S.N., and V.V.E.; Formal analysis, B.N.; Investigation, V.N., G.M., B.N., and S.N.; Software, B.N.; Resources, L.P., F.M., and V.V.E.; Data curation, L.P. and F.M.; Writing-original draft preparation, B.N.; Writing-review \& editing, L.P., B.N., F.M., and V.V.E.; Visualization, L.P., B.N., F.M., and V.V.E.; Supervision, L.P., B.N., F.M., and V.V.E.; Project administration, L.P. and F.M.; Funding acquisition, F.M. and V.V.E. All authors have read and agreed to the published version of the manuscript. 
Funding: This research received no external funding.

Conflicts of Interest: The authors declare no conflict of interest.

\section{References}

1. Hilliard, O.M. Gnaphaliinae. In Flora of Southern Africa: Asteraceae; Leistner, O.A., Ed.; South African National Botanical Institute: Pretoria, South African, 1983; Volume 33, pp. 1-325.

2. Lourens, A.C.U.; Viljoen, A.M.; van Heerden, F.R. South African Helichrysum species: A review of the traditional uses, biological activity and phytochemistry. J. Ethnopharmacol. 2008, 119, 630-652. [CrossRef] [PubMed]

3. Lourens, A.C.U.; Van Vuuren, S.F.; Viljoen, A.M.; Davids, H.; Van Heerden, F.R. Antimicrobial activity and in vitro cytotoxicity of selected South African Helichrysum species. South Afr. J. Bot. 2011, 77, 229-235. [CrossRef]

4. Mamabolo, M.P.; Muganza, F.M.; Tabize Olivier, M.; Olaokun, O.O.; Nemutavhanani, L.D. Evaluation of antigonorrhea activity and cytotoxicity of Helichrysum caespititium (DC) Harv. Whole plant extracts. Biol. Med. 2018, 10, 1-4. [CrossRef]

5. Maroyi, A. Helichrysum caespititim (DC.) Harv.: Review of its medicinal uses, phytochemistry and biological activities. J App Pharm Sci. 2019, 9, 111-118.

6. Maroyi, A. A synthesis and review of medicinal uses, phytochemistry and biological activities of Helichrysum odoratissimum L. Sweet. Asian J. Pharm. Clin. Res. 2019, 12, 15-23. [CrossRef]

7. Maroyi, A. Helichrysum petiolare hilliard and B. L. burtt: A review of its medicinal uses, phytochemistry, and biological activities. Asian J. Pharm. Clin. Res. 2019, 12, 32-37. [CrossRef]

8. Popoola, O.K.; Marnewick, J.L.; Rautenbach, F.; Iwuoha, E.I.; Hussein, A.A. Acylphloroglucinol derivatives from the south african Helichrysum niveum and their biological activities. Molecules 2015, 20, 17309-17324. [CrossRef] [PubMed]

9. Yazdi, S.E.; Prinsloo, G.; Heyman, H.M.; Oosthuizen, C.B.; Klimkait, T.; Meyer, J.J.M. Anti-HIV-1 activity of quinic acid isolated from Helichrysum mimetes using NMR-based metabolomics and computational analysis. South Afr. J. Bot. 2019, 126, 328-339. [CrossRef]

10. Lourens, A.C.U.; Reddy, D.; Başer, K.H.C.; Viljoen, A.M.; Van Vuuren, S.F. In vitro biological activity and essential oil composition of four indigenous South African Helichrysum species. J. Ethnopharmacol. 2004, 95, 253-258. [CrossRef] [PubMed]

11. Bougatsos, C.; Meyer, J.J.M.; Magiatis, P.; Vagias, C.; Chinou, I. Composition and antimicrobial activity of the essential oils of Helichrysum kraussii Sch. Bip. and H. rugulosum Less. from South Africa. Flavour Fragr. J. 2003, 18, 48-51. [CrossRef]

12. Yani, V.V.; Oyedeji, O.A.; Grierson, D.S.; Afolayan, A.J. Chemical analysis and antimicrobial activity of essential oil extracted from Helichrysum aureonitens. South Afr. J. Bot. 2005, 71, 250-252. [CrossRef]

13. Van Vuuren, S.F.; Viljoen, A.M.; van Zyl, R.L.; van Heerden, F.R.; Başer, K.H.C. The antimicrobial, antimalarial and toxicity profiles of helihumulone, leaf essential oil and extracts of Helichrysum cymosum (L.) D. Don subsp. cymosum. South Afr. J. Bot. 2006, 72, 287-290. [CrossRef]

14. Asekun, O.T.; Grierson, D.S.; Afolayan, A.J. Characterization of essential oils from Helichrysum odoratissimum using different drying methods. J. Appl. Sci. 2007, 7, 1005-1008.

15. Samie, A.; Nefefe, T.; Gundidza, M.; Mmbengwa, V.; Magwa, M.; Mtshali, M.S. Antimicrobial activities and time kill profiles of five essential oils from Southern Africa against selected bacterial and fungal organisms. Afr. J. Pharm. Pharmacol. 2012, 6, 3086-3095. [CrossRef]

16. Ras, A.M. Essential oil yield and composition of three Helichrysum species occurring in the Eastern Cape province of South Africa. South Afr. J. Bot. 2013, 86, 181. [CrossRef]

17. Lawal, O.A.; Ogunwande, I.A.; Kasali, A.A.; Opoku, A.R.; Oyedeji, A.O. Chemical composition, antibacterial and cytotoxic activities of essential oil from the leaves of Helichrysum odoratissimum grown in South Africa. J. Essent. Oil-Bearing Plants 2015, 18, 236-241. [CrossRef]

18. Mashigo, M.; Combrinck, S.; Regnier, T.; Du Plooy, W.; Augustyn, W.; Mokgalaka, N. Chemical variations, trichome structure and antifungal activities of essential oils of Helichrysum splendidum from South Africa. South Afr. J. Bot. 2015, 96, 78-84. [CrossRef] 
19. Van Vuuren, S.; Ramburrun, S.; Kamatou, G.; Viljoen, A. Indigenous South African essential oils as potential antimicrobials to treat foot odour (bromodosis). South Afr. J. Bot. 2019, 126, 354-361. [CrossRef]

20. Reidel, R.V.B.; Cioni, P.L.; Ruffoni, B.; Cervelli, C.; Pistelli, L. Aroma profile and essential oil composition of Helichrysum species. Nat. Prod. Commun. 2017, 12, 1507-1512.

21. Giovanelli, S.; De Leo, M.; Cervelli, C.; Ruffoni, B.; Ciccarelli, D.; Pistelli, L. Essential oil composition and volatile profile of seven Helichrysum species grown in Italy. Chem. Biodivers. 2018, 15, e1700545. [CrossRef]

22. Najar, B.; Cervelli, C.; Ferri, B.; Cioni, P.L.; Pistelli, L. Essential oils and volatile emission of eight South African species of Helichrysum grown in uniform environmental conditions. South Afr. J. Bot. 2019, 124, 178-187. [CrossRef]

23. Gundidza, M.G.; Zwaving, J.H. Antimicrobial and antioxidant activities of the essential oil from Helichrsum odoratissimum. J. Essent. Oil Res. 1993, 5, 341-343. [CrossRef]

24. Lwande, W.; Hassanali, A.; Wanyama, O.B.; Ngola, S. Constituents of the essential oil of Helichrysum odoratissimum. J. Essent. Oil Res. 1993, 5, 93-95. [CrossRef]

25. Kuiate, J.R.; Amvam Zollo, P.H.; Nguefa, E.H.; Bessière, J.M.; Lamaty, G.; Menut, C. Composition of the essential oils from the leaves of Microglossa pyrifolia (Lam.) O. Kuntze and Helichrysum odoratissimum (L.) Less. growing in Cameroon. Flavour Fragr. J. 1999, 14, 82-84. [CrossRef]

26. Cavalli, J.F.; Ranarivelo, L.; Ratsimbason, M.; Bernardini, A.F.; Casanova, J. Constituents of the essential oil of six Helichrysum species from Madagascar. Flavour Fragr. J. 2001, 16, 253-256. [CrossRef]

27. Van Vuuren, S.F.; Viljoen, A.M. Antimicrobial activity of limonen enantiomers and 1,8-cineole alone and in combination. Falv Frag J. 2007, 22, 540-544. [CrossRef]

28. Costa, M.D.S.; Rocha, J.E.; Campina, F.F.; Silva, A.R.P.; Da Cruz, R.P.; Pereira, R.L.S.; Quintans-Júnior, L.J.; De Menezes, I.R.A.; Adriano, A.A.; De Freitas, T.S.; et al. Comparative analysis of the antibacterial and drug-modulatory effect of D-limonene alone and complexed with $\beta$-cyclodextrin. Eur. J. Pharm. Sci. 2019, 128, 158-161. [CrossRef]

29. Doughari, J.H.; Bazza, M.J. Phytochemistry, GC-MS analysis, antioxidant and antibacterial potentials of limonene isolated from pericarp of citrus sinensis. Inter. J. Microbiol. Biotechnol. 2010, 5, 22-27. [CrossRef]

30. Adams, R.P.; Dev, V. Synthesis and GC-MS analysis of angelates and tiglates as an aid to identification of these components in essential oils. Flav Frag J. 2010, 25, 71-74. [CrossRef]

31. Samie, A.; Nefefe, T. Antifungal activities of essential oils from Southern African medicinal plants against five Fusariun species. J. Med Plants Rs. 2012, 6, 464-478.

32. Maroyi, A. Medicinal uses, biological and phytochemical properties of Helichrysum foetidum (L.) moench. (Asteraceae). Asian J. Pharm. Clin. Res. 2019, 12, 13-18. [CrossRef]

33. Bougatsos, C.; Ngassapa, O.; Runyoro, D.K.B.; Chinou, I.B. Chemical composition and in vitro antimicrobial activity of the essential oils of two Helichrysum species from Tanzania. Zeitschrift für Naturforschung C 2004, 59, 368-372. [CrossRef] [PubMed]

34. Matsushita, Y.I.; Hwang, Y.H.; Sugamoto, K.; Matsui, T. Antimicrobial activity of heartwood components of sugi (Cryptomeria japonica) against several fungi and bacteria. J. Wood Sci. 2006, 52, 552-556. [CrossRef]

35. Magina, M.D.A.; Dalmarco, E.M.; Wisniewski, A.; Simionatto, E.L.; Dalmarco, J.B.; Pizzolatti, M.G.; Brighente, I.M.C. Chemical composition and antibacterial activity of essential oils of Eugenia species. J. Nat. Med. 2009, 63, 345-350. [CrossRef]

36. Mehalaine, S.; Belfadel, O.; Menasria, T.; Messaili, A. Composition chimique et activité antibactérienne des huiles essentielles de trois plantes médicinales récoltées de la région semi-aride algérienne. Phytotherapie 2017, 85, 1-9.

37. Chinou, I.B.; Bougatsos, C.; Perdetzoglou, D. Chemical composition and antimicrobial activities of Helichrysum amorginum cultivated in Greece. J. Essent. Oil Res. 2004, 16, 243-245. [CrossRef]

38. Vukovic, N.; Milosevic, T.; Sukdolak, S.; Solujic, S. Antimicrobial activities of essential oil and methanol extract of Teucrium montanum. Evid.-Based Complement. Altern. Med. 2007, 4, 17-20. [CrossRef]

39. González, A.M.; Tracanna, M.I.; Amani, S.M.; Schuff, C.; Poch, M.J.; Bach, H.; Catalán, C.A.N. Chemical composition, antimicrobial and antioxidant properties of the volatile oil and methanol extract of Xenophyllum poposum. Nat. Prod. Commun. 2012, 7, 1663-1666. [CrossRef]

40. Chang, H.T.; Cheng, Y.H.; Wu, C.L.; Chang, S.T.; Chang, T.T.; Su, Y.C. Antifungal activity of essential oil and its constituents from Calocedrus macrolepis var. formosana Florin leaf against plant pathogenic fungi. Bioresour. Technol. 2008, 99, 6266-6270. 
41. Fahed, L.; Khoury, M.; Stien, D.; Ouaini, N.; Eparvier, V.; El Beyrouthy, M. Essential oils composition and antimicrobial activity of six conifers harvested in lebanon. Chem. Biodivers. 2017, 14, 1-7. [CrossRef]

42. Parasuraman, S.; Yu Ren, L.; ChikChuon, B.L.; Wong Kah Yee, S.; Ser Qi, T.; Christapher, J.P.V.; Venkateskumar, K.; Raj, P.V. Phytochemical, antimocrobial and mast cell stabilizing activity of ethanolic extract of Solanum trilobatum Linn. leaves. Malaysian J. Microbiol. 2016, 12, 359-364.

43. Abu-Darwish, M.S.; Cabral, C.; Ferreira, I.V.; Gonçalves, M.J.; Cavaleiro, C.; Cruz, M.T.; Albdour, T.H.; Salgueiro, L. Essential oil of common sage (Salvia officinalis L.) from Jordon: Assessment of safety in mammalian cells and its antifungal and anti-inflammatory potential. BioMed Res. Int. 2013, 1-9. [CrossRef] [PubMed]

44. Jaafar, M.; Mitri, S.; Nawas, T. Inhibition of gram-negative bacterial growth and biofilm formation by alpha thujone. ISOR-JPBS. 2018, 13, 40-47.

45. Galvez, C.E.; Jimenez, C.M.; Gomez, A.; de los, A.; Lizarraga, E.F.; Sampietro, D.A. Chemical composition and antifungal activity of essential oils from Senecio nutans, Senecio viridis, Tagetes terniflora and Aloysia gratissima against toxigenic Aspergillus and Fusarium species. Nat. Prod. Res. 2018, 34, 1-4. [CrossRef]

46. Bremner, P.D.; Meyer, J.J.M. Oinocembrin chalcone: An antibacterial compound from Helichrysum trilineatum. Planta Med. 1998, 64, 777. [CrossRef]

47. Brevard, H.; Cantergiani, E.; Cachet, T.; Chaintreau, A.; Demyttenaere, J.; French, L.; Gassenmeier, K.; Joulain, D.; Koenig, T.; Leijs, H.; et al. Guidelines for solid-phase micro-extraction (SPME) of volatile flavour compounds for gas-chromatographic analysis, from the Working Group on Methods of Analysis of the International Organization of the Flavor Industry (IOFI). Flavour Fragr. J. 2010, 25, 404-406.

48. European Pharmacopoeia; Maisonneuve SA: Sainte Ruffine, France, 1975; Volume 3, p. 68.

49. Adams, R.P. Identification of Essential Oil Components by Gas Chromatography/Quadrupole Mass Spectroscopy; Allured Publishing Corporation: Carol Stream, IL, USA, 1995.

50. Davies, N.W. Gas chromatographic retention indices of monoterpenes and sesquiterpenes on methyl silicon and Carbowax 20M phases. J. Chromatogr. A 1990, 503, 1-24. [CrossRef]

51. Jennings, W.; Shibamoto, T. Qualitative Analysis of Flavor and Fragrance Volatiles by Glass Capillary Gas Chromatography; Elsevier: London, UK, 1982.

52. Masada, Y. Analysis of Essential Oils by Gas Chromatography and Mass Spectrometry; John Wiley \& Sons: New York, NY, USA, 1976.

53. Stenhagen, E.; Abrahamsson, S.; McLafferty, F.W. Registry of Mass Spectral Data; Wiley \& Sons: New York, NY, USA, 1974.

54. Swigar, A.A.; Silverstein, R.M. Monoterpenes; Aldrich Chemical Company: Milwaukee, WI, USA, 1981.

55. CLSI. Performance Standards for Antimicrobial Disk Susceptibility Tests, Approved Standard, 11th ed.; Clinical and Laboratory Standards Institute: Wayne, PA, USA, 2012; pp. 1-15.

56. Methods for dilution antimicrobial susceptibility tests for bacteria that grow aerobically. In CLSI-National Committee for Clinical Laboratory Standards, Approved standard M7-A2; National Committee for Clinical Laboratory Standards: Wayne, PA, USA, 1990.

57. Ebani, V.V.; Nardoni, S.; Bertelloni, F.; Giovanelli, S.; Rocchigiani, G.; Pistelli, L.; Mancianti, F. Antibacterial and antifungal activity of essential oils against some pathogenic bacteria and yeasts shed from poultry. Flavour Fragr. J. 2016, 31, 302-309. [CrossRef]

58. Zhang, Z.; Castelló, A. Principal components analysis in clinical studies. Ann. Transl. Med. 2017, 5, 3-9. [CrossRef]

Sample Availability: Samples of the plant species are available from the authors (CREA, Sanremo, Italy). 